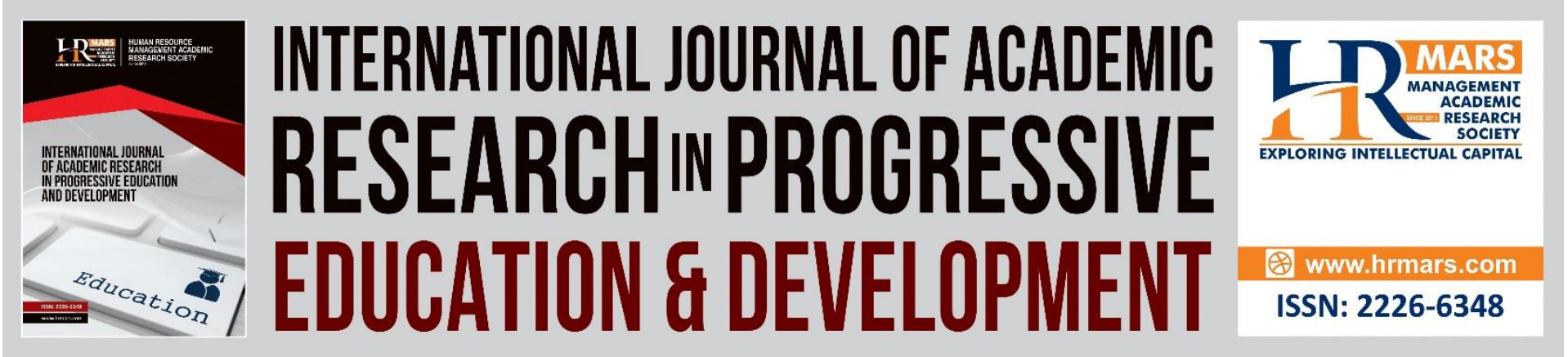

\title{
The Effect of Collaborative Strategic Reading on ESL Students' Reading Comprehension Through Online Teaching
}

Heng Hui Ying, Geetha Veerappan

To Link this Article: http://dx.doi.org/10.6007/IJARPED/v10-i3/10510

DOI:10.6007/IJARPED/v10-i3/10510

Received: 11 June 2021, Revised: 14 July 2021, Accepted: 24 July 2021

Published Online: 25 August 2021

In-Text Citation: (Ying \& Veerappan, 2021)

To Cite this Article: Ying, H. H., \& Veerappan, G. (2021). The Effect of Collaborative Strategic Reading on Esl Students' Reading Comprehension Through Online Teaching. International Journal of Academic Research in Progressive Education and Development, 10(3), 517-530.

Copyright: (C) 2021 The Author(s)

Published by Human Resource Management Academic Research Society (www.hrmars.com)

This article is published under the Creative Commons Attribution (CC BY 4.0) license. Anyone may reproduce, distribute, translate and create derivative works of this article (for both commercial and non-commercial purposes), subject to full attribution to the original publication and authors. The full terms of this license may be seen

at: http://creativecommons.org/licences/by/4.0/legalcode

Vol. 10 (3) 2021, Pg. 517 - 530

Full Terms \& Conditions of access and use can be found at http://hrmars.com/index.php/pages/detail/publication-ethics 


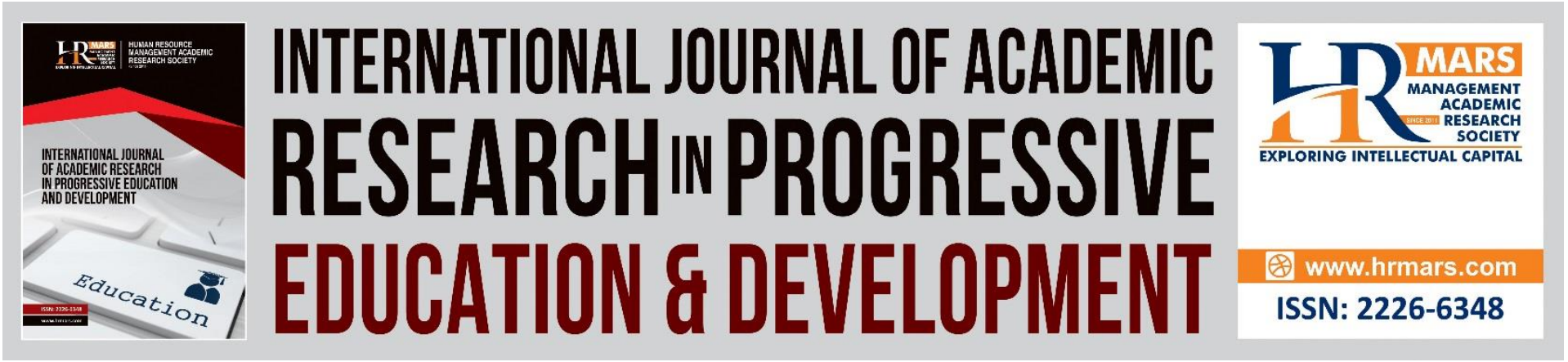

\title{
The Effect of Collaborative Strategic Reading on ESL Students' Reading Comprehension Through Online Teaching
}

\author{
Heng Hui Ying ${ }^{1}$, Geetha Veerappan² \\ ${ }^{1}$ Universiti Tunku Abdul Rahman, ${ }^{2}$ Universiti Tunku Abdul Rahman \\ Email: huiying-97@hotmail.com, geethav@utar.edu.my
}

\begin{abstract}
The purpose of this study are to investigate the effect of Collaborative Strategic Reading (CSR) on the reading comprehension of ESL secondary school students through online teaching and to find out the ESL secondary school students' perceptions of the Collaborative Strategic Reading approach in online teaching. Ten secondary school students in Malaysia participated in this study. This study adopted an experimental design which is pre-test and post-test with a control group and an interview. In the experimental group, the students were taught using CSR while the students in the control group were taught in the traditional way. The result indicated that CSR had a positive effect on ESL secondary school students' reading comprehension. However, the statistical analysis did not show that CSR significantly improve reading comprehension of the students compared with the traditional teacher-centered approach. The results of interview further proved that all students held a positive attitude towards CSR approach. Some suggestions for future research to further validate the effectiveness of CSR are also provided.
\end{abstract}

Keywords: Reading Comprehension, Collaborative Strategic Reading, ESL Secondary School Learners, Online Teaching, Group Work

\section{Introduction}

Online learning and teaching is a kind of distance learning which encompasses a wide range of technology applications. It also includes several learning processes such as computer-based learning, virtual learning, web-based learning and also digital collaborations. Online teaching and learning also called e-learning is the formal and informal learning process through electronic methods which includes Internet, DVD, videotapes, CD-ROM and so on. According to Campbell (2004), as cited in (Keengwe \& Kidd, 2010), online learning focuses on the development of metacognitive, collaborative and reflective learning.

Reading is one of the important language skills which leads to students' social, personal, and professional development (Khonamri \& Karimabadi, 2015). According to Alqarnin (2015); Khonamri \& Karimabadi (2015), reading is not an easy but a complex process that requires the readers to know and comprehend the words and sentence pattern. Hence, readers need to be trained with certain types of skills and abilities to learn, comprehend, and react to the reading successfully. Alamin \& Ahmed (2014) stated that poor learning will lead 
to failure to enhance learning as a strategic reading that does not promote comprehension of reading while strategic reading helps in it. Therefore, many researchers have focused on the importance of preparing language learners to become strategic learners (Fan, 2010; Karabuga \& Kaya, 2013). Strategic reading fosters the autonomy and the self-awareness of the process of meaning construction of the learners. It also helps in improving academic reading performance of learners (Fan, 2010). Therefore, many researchers and educators have tried to create different reading approaches or methods in different contexts, opportunities and implementation.

Among all the approaches and methods developed by the researchers, the Collaborative Reading Strategic (CSR) approach is designed to facilitate reading comprehension of learners in general education classrooms. Cooperative learning is important in incorporating this approach as the learners support their learning with teachers and peers (Karabuga \& Kaya, 2013). There are three phrases in the CSR approach which intend to activate the background knowledge of the students, identify the main points in the text, monitor students' understanding and recognize the confusing words or ideas. The three phrases are which include before, during and after reading activities (Klingner et al., 2012). The present study aims to identify the effect of CSR on ESL secondary school students' reading comprehension through online teaching.

\section{Literature Review}

Research has been interested in the implementation of CSR from different perspectives with participants in different educational settings. Oladele \& Oladele (2016) had conducted research on EFL learners with learning disabilities. The study was conducted to find out the effectiveness of CSR and whole language approach (WLA) on reading comprehension of primary school children with learning disabilities. There were seventy-eight primary school students with learning disabilities in Oyo State Nigeria participated in this study. The resulted showed that students who were taught using CSR had a better performance compared with the WLA group in the post-test. The result proved that CSR is an effective approach in improving learners' reading comprehension.

The research conducted by Wang (2008) had evaluated the effect of CSR on sixthgraders' reading comprehension and learning attitudes. 62 students from two classes were selected to participate in this study. Questionnaires, pre-reading comprehension tests and post-reading comprehension tests were used to identify the effectiveness of CSR approach. The result showed that the CSR approach is effective in improving the learners' reading comprehension and thus increasing their English learning motivation. A study conducted by Klingner and Vaughn (1996) had used a modified reciprocal teaching approach which involves peer-led cooperative group discussions. The participants in this study were twenty-six 7 th and 8th ESL graders with learning disabilities in the United States. The researchers attempted to compare the effect of peer-led discussion in cooperative learning groups and the effect of reciprocal teaching with cross-age tutoring. The results showed that both reading approaches help in learners' reading comprehension. The results indicate that ESL students with learning disabilities could benefit from CSR approach with minimal support from teacher or adult as well as similar learners who received support from the teacher in reciprocal teaching.

Another study conducted by Husni, Manurung \& Kamarudin (2017) investigated the influence of CSR on students' reading comprehension achievement of narrative text. Twentyone 3 IPA 1 students at MAN 2 Model Palu were selected as the sample of the study. This 
research used a pre-experimental research design which was a pre-test-post-test one group design. The finding suggested the students liked the idea of group work and group discussion as these made the comprehension process easier. The result showed that CSR technique contributes a lot in fostering learners' reading comprehension achievement.

In another research conducted by Gani, Yusuf \& Susiani (2016), the study aimed to identify the effectiveness of CSR in teaching reading to EFL students in Indonesia. Sixty-seven senior high school students in Indonesia were randomly chosen and involved as the participants, 32 students were in the experimental group and 35 students were in the control group. The study also adopted an experimental method. The instruments involved were preand post-test and a questionnaire. The finding proved that CSR a helps in fostering EFL students' reading comprehension. The finding of the questionnaire further indicated that the learners gave positive responses to the implementation of CSR in the classroom.

Based on Kabir \& Kiasi (2018), the study aimed to investigate the effect of CSR on the achievements in English reading comprehension and vocabulary of Iranian EFL secondary school students. An experimental design was used to identify the differences in reading comprehension achievements and vocabulary of students gain in CSR and traditional instruction. 40 students were divided randomly into an experimental group and a control group with each group 20 students. The findings suggested that CSR positively affected the experimental group learners' reading comprehension and vocabulary acquisition.

The work of Klingner and Vaughn (1996); Husni, Manurung \& Kamarudin (2017); Gani, Yusuf \& Susiani (2016); Kabir \& Kiasi (2018) proved that CSR is an effective approach to teach reading comprehension not only for primary school students but also secondary school students.

Fan (2010) studied the effect of CSR on reading comprehension of Taiwanese university students as regards to specific types of reading comprehension questions to investigate the effectiveness of CSR instruction. 117 intermediate students from two classes were divided into two groups. The control group adopted a traditional teaching approach while the experimental group adopt a CSR approach for 14 weeeks. This study used a mixedmethod and included pre- and post-test, a questionnaire and interviews. The finding had suggested that CSR was positively affected the reading comprehension of university students.

The paper written by Karabuga \& Kaya (2013) aims to investigate the effect of CSR approach on reading comprehension and reading-related problems of adult EFL Learners. 40 prep-class university students in Kahramanmaras Stucu Imam University were chosen as the sample by using a convenience sampling method. This study used an experimental method and a descriptive method in conducting the research. The instruments involved were the preand post-tests, minute papers about learners' reading-related problems, CSR Learning Log, Reflective Learning Log and researcher's field notes. The findings showed that many readingrelated problems of the participants were observed to be decreased or even eliminated with using CSR approach. The result proved that CSR affected positively on' reading comprehension of adult EFL learners.

Zoghi, Mustapha \& Maasum (2010) had conducted a research to find out the effectiveness of Modified Collaborative Strategic Reading approach in enhancing university first-year EFL students' reading comprehension. Forty-two Engineering students from a university located in the East- Azerbaijan province of Iran had been selected as the sample in this study. A mixed method study which was a qualitative method and a quantitative method had been used in this study. The finding of the qualitative evaluation showed that there was 
no significant difference in students' mean scores. This proved that CSR did not positively affect the participants' reading comprehension. However, the finding of qualitative evaluation revealed that a few of the students did show minimal responsiveness to MCSR.

The researchers, Alamin \& Ahmed (2014) designed a case study to examine the effect of CSR on Taif University. 79 male students and 55 female students from classes of English at the Department of Foreign Languages of Arts College have participated in this study. Questionnaires were used in this study to collect the data. The results are inconsistent as the researches mentioned above. The study had concluded that CSR was not effective on reading comprehension of Taif University students in Indonesia. The researchers speculate that it was due to time constraint given to the participants to learn and apply CSR. Besides, the participants have to answer three questionnaires and it will be time-consuming and difficult for the researchers to analysis all the data.

\section{Problem Statement}

Malaysian students' low performance in reading in PISA literacy test 2018 drew the attention of the researchers to ESL secondary school learners' reading comprehension abilities. According to OECD (2019), the score of Malaysian students was 415 in reading which was below the global average score of 487 . The result showed that Malaysian students did not perform well in the field of reading. As mentioned in the research conducted by Javed et al (2016), Malaysian students' poor performance in reading comprehension may have been due to the way ESL teachers teach ESL learners' reading comprehension. The result has shown that students' performances are depending on how teachers use reading strategies to teach reading comprehension. In addition, many studies have been done on CSR with primary classroom, secondary classroom or university content with L1 or EFL learners from different countries to study the effect of CSR on learners' reading comprehension (Khonamri \& Karimabadi, 2015). Most of the results of the past studies show the practice of CSR does help learners in improving their reading comprehension skills and performances. However, there is no research being done in any Malaysian classroom context. Therefore, the present study aims to find out the effect of CSR on the reading comprehension of ESL secondary school students through online teaching and to find out the ESL secondary school students' perceptions of the CSR approach in online teaching.

\section{Methodology}

Mixed method research was designed for this study which included an experimental method and an interview. The experimental method was used to investigate the effect of CSR on the reading comprehension of ESL secondary school students. The experimental research method involved pre-test, treatment, and post-test. There were two groups which were an experimental group and a control group involving in the study. An online pre-reading comprehension test was conducted for both groups and the scores were calculated and analyzed. Then, the experimental group was taught using the CSR approach while the control group was taught using a traditional teacher-centred teaching approach. The treatment was conducted for 10 online teaching lessons. After the 10 online teaching lessons, both groups did on an online post-reading comprehension test and the scores were calculated and analyzed. After post-test, an interview session was conducted to interview students in the experimental group in order to identify their perception towards the implementation procedure of CSR after the post-test. 
DEVELOPMENT

Vol. 10, No. 3, 2021, E-ISSN: 2226-6348 @ 2021 HRMARS

Identified by snowball sampling method, the samples in this study were 10 Form 3 students who are currently studying in secondary school in Malaysia. The researcher divided the 10 samples into two groups which was a control group and an experimental group. Each group consisted of 5 students. Meanwhile, the sampling method used to choose 5 students for the interview was judgmental sampling. The samples were chosen critically to maximize the outcomes of the interview. The interview will only be conducted to the 5 samples from the experimental group as the interview aims to collect the perception of ESL secondary school students on CSR approach in teaching.

\section{General Procedures for this Research Consisted of}

\section{(a) Orientation session for CSR}

Before the treatment, the teacher will explain what CSR is and demonstrates the whole process to the experimental group for a week. Cue sheets will be used to outline CSR approach procedures in this stage. They include the details on how to apply the four reading strategies for reading comprehension in CSR. A cue sheet sample is shown in Appendix A.

The teacher will explain explicitly to students on why, when and how to use these four reading strategies. Instead of explaining the implementation of each strategy separately, the teacher will make it related to the content. The teacher then introduces the previewing strategy before asking the students to read the entire text. At this stage, students will be asked to look at the headings, words or subtitles in bold, graphs, and pictures to brainstorm what they had known about the topic. They also need to predict what they would learn and make inferences about the purpose of the author. Additionally, they will be asked to review and discuss the pre-reading questions in order to help in activating their background knowledge about the topics.

In the Click and Clunk stage, students will need to identify the meaning of clunks (unknown and difficult words or phrases) during the reading. Students will be asked to write down the meaning and how they solved the clunks on the CSR learning log.

The next strategy will be taught to students is Get the Gist strategy. Students will be learnt on how to identify the topic sentence for every paragraph to help undifferentiating the main idea from the supporting statements in the text.

The last strategy is the wrap-up stages. Students will be trained to ask some questions which involve higher-order thinking skills at this stage. Students can ask questions on information which had stated in the text or questions with the answer that could not found in the text. These questions will be used to check students' reading comprehension.

After explaining the four stages in CSR, the teacher introduces four students' roles in CSR. The four roles are as below:

1. Leader- The student who leads the group discussion.

2. Clunk expert- The student who helps others to deal with clunks (the meaning of difficult words or phrases).

3. Gist expert- The student who helps others to get the important idea in the texts.

4. Reporter- The student who helps others to summarize the main idea of the texts.

5. Encourager- The student who observes the discussion and provide feedback.

Then, the teacher asks students to form groups consisting of 5 students. Each group member will be assigned a defined role to facilitate the group work. Students will stay in the same 
DEVELOPMENT

Vol. 10, No. 3, 2021, E-ISSN: 2226-6348 @ 2021 HRMARS

group during all the CSR lessons, but they will exchange their roles every week to boost the participation and experience various roles of the tasks.

(b) Pre testing and post testing

Pre-test was conducted before the start of CSR implementation. On the other hand, post-test was conducted during the class after the completion of the 10 CSR session. 5 reading passages with 25 multiple-choice questions were administered in both reading comprehension tests. Both tests were conducted online. Quantitative data from both tests were collected to examine reading comprehension of the students. After the post-test, an interview was conducted to the experimental group to collect their perceptions of CSR. The interview consists of 6 questions and the questions are presented in Google Form. Statistical analysis was used to analyze the data of the experimental study while thematic analysis was used to analyze the data of the interview.

Findings

Pre-test and Post-test

Table 1 Pre-test and Post-test score for Experimental Group and Control Group

\begin{tabular}{|c|c|c|c|c|c|}
\hline \multicolumn{3}{|l|}{ Experimental Group } & \multicolumn{3}{|l|}{ Control Group } \\
\hline \multirow[t]{2}{*}{ Student } & Pre-test & Post-test & \multirow[t]{2}{*}{ Student } & Pre-test & Post-test \\
\hline & $\left(X_{1}\right)$ & $\left(X_{2}\right)$ & & $\left(Y_{1}\right)$ & $\left(Y_{2}\right)$ \\
\hline 1 & 64 & 76 & 1 & 32 & 52 \\
\hline 2 & 72 & 88 & 2 & 64 & 68 \\
\hline 3 & 40 & 72 & 3 & 56 & 72 \\
\hline 4 & 48 & 76 & 4 & 40 & 56 \\
\hline 5 & 40 & 72 & 5 & 36 & 60 \\
\hline$\sum N_{1}=5$ & $\sum X_{1}=264$ & $\sum X_{2}=384$ & $\sum N_{2}=5$ & $\sum Y_{1}=228$ & $\sum Y_{2}=308$ \\
\hline Mean & 52.8 & 76.8 & Mean & 45.6 & 61.6 \\
\hline Standard Deviation & 29.07 & 13.15 & Standard Deviation & 27.48 & 16.59 \\
\hline
\end{tabular}

From the table above, it can be seen that all 5 students from experimental group scored higher on the post-test than the pre-test. The mean for pre-test was 52.8 and the mean for post-test was 76.8. The standard deviation of pre-test was 29.07 and the standard deviation for post-test was 13.15 (see table 1). Besides, all 5 students from control group scored higher on the post-test than the pre-test. The mean for pre-test was 45.6 and the standard deviation was 27.48. The mean of post-test was 61.6 and the standard deviation was 16.59 .

Statistical Analysis for Pre-test and Post Test

T-test Comparing Pre-test Mean

Before beginning the treatment, the critical reading performance of students from both groups were needed to be compared to ensure that their levels are not much different. Independent sample t-test was conducted in order to find out whether there were any significant differences between the two groups in the pre-test. The result was presented in table 1. 
INTERNATIONAL JOURNAL OF ACADEMIC RESEARCH IN PROGRESSIVE EDUCATION AND

DEVELOPMENT

Vol. 10, No. 3, 2021, E-ISSN: 2226-6348 @ 2021 HRMARS

Table 2: Independent Samples T-test Comparing Pre-test Mean of the Control and Experimental Groups

\begin{tabular}{|l|l|l|l|l|l|l|}
\hline & Sig & T & df & $\begin{array}{l}\text { Sig (2- } \\
\text { tailed) }\end{array}$ & $\begin{array}{l}\text { Mean } \\
\text { Difference }\end{array}$ & $\begin{array}{l}\text { Std } \\
\text { difference }\end{array}$ \\
\hline $\begin{array}{l}\text { Equal variance } \\
\text { assumed }\end{array}$ & 0.636 & - & 8 & 0.727 & -6.48 & 17.890 \\
\hline $\begin{array}{l}\text { Equal variance not } \\
\text { assumed }\end{array}$ & & $\begin{array}{l}0.362 \\
0.362\end{array}$ & 7 & 0.727 & -6.48 & 17.890 \\
\hline
\end{tabular}

Based on table 2 , the gained $t$ value was -0.362 while the $p$ value was $0.727>0.05$. Therefore, it can be said that there was no significant difference between both experimental and control groups. The result showed that students from both groups had a similar critical reading performance.

T-test Comparing Post Test Mean

Students from both groups were given a post reading comprehension test after the treatment in order to investigate the effectiveness of CSR on reading comprehension. The result was analyzed using a two-tailed independent samples t-test to determine whether the students in experimental group performed better compared to the students in control group after receiving different reading strategies approaches. The statistical result was presented in table 3.

Table 3 Independent Samples T-test Comparing Post-test Mean of the Control and Experimental Groups

\begin{tabular}{|c|c|c|c|c|c|c|}
\hline & Sig & $\mathrm{T}$ & $\mathrm{df}$ & $\begin{array}{l}\text { Sig } \\
\text { tailed })\end{array}$ & $\begin{array}{l}\text { Mean } \\
\text { Difference }\end{array}$ & $\begin{array}{l}\text { Std error } \\
\text { difference }\end{array}$ \\
\hline $\begin{array}{ll}\text { Equal } & \text { variance } \\
\text { assumed } & \end{array}$ & 0.924 & $\begin{array}{l}- \\
1.606\end{array}$ & 8 & 0.147 & -15.2 & 9.4673 \\
\hline $\begin{array}{l}\text { Equal variance not } \\
\text { assumed }\end{array}$ & & - & 7 & 0.152 & -15.2 & 9.4673 \\
\hline
\end{tabular}

Based on table 3 , the gained $t$ value was -1.606 while the $p$ value was $0.147>0.05$. Therefore, it can be said that there was no significant difference between both experimental and control groups. The result showed that CSR approach was not shown to be more effective compared to the traditional teaching-centered approach in terms of its effectiveness in improving the ESL secondary school students' reading comprehension.

\section{Findings of Interview}

This section presented the qualitative data analysis related to the students' perceptions of CSR approach. An interview was conducted to the experimental group. Students were asked six questions designed to know how they felt about CSR in learning reading and their thoughts on using CSR in reading class. Six key themes have emerged from the thematic analysis of the interviews which were 1) General views about CSR; 2) Positive features of CSR; 3) Advantages of (SR; 4) Disadvantages of CSR; 5) Dilemmas encountered in CSR; and 6) willingness to continue with CSR approach.

\section{General views about CSR}

The qualitative data analysis showed that $100 \%$ of the students had positive perceptions about the CSR approach. Their comments also suggested that using CSR strategy in learning 
reading was preferred by students. The major reasons which aroused students' interest in CSR were the group work which the students had engaged and also because of the CSR approach was more interesting compared to the traditional teaching method used in the normal classroom. The excerpts below showed the examples of their statements:

Yes, I like using CSR because it is fun to have discussion with my friends. (Kai Qi)

Yes, I like using CSR strategy in learning reading because it is interesting and I will not feel boring in the class. (Yuen Sin)

Yes, because in normal reading class I will feel very boring but in CSR class I can feel my responsibility as I am given a role to perform in the class. (Stacy)

\section{Positive Features of CSR}

According to the qualitative data, both click and clunk strategy and get the gist strategy were the most helpful strategy in CSR approach. Students had suggested that click and clunk strategy helped improve their vocabulary and understanding about the reading materials. Besides, students also commented that with the use of clunk cards, there were able to identify the meaning of difficult words without using a dictionary. The following excerpts below showed the examples of their comments related to click and clunk strategy:

Using clunk cards help me to get rid of using dictionary which I cannot use in examination to find the meaning of words. (Cai Ying)

I like click and clunk strategy the most. By using 4 clunk cards, I am able to understand the difficult words in the text without referring to the dictionary. (Tiffany)

It improves my vocabulary and I can understand the passage better. (Kai Qi)

On the other hand, get the gist strategy was helpful for students in identifying the important points and main idea in the passage. With this strategy, students would had a better understanding on what the passage was about. For example, some of the students commented:

Get the gist. Because it helps me to identify the important ideas and thus more understand the passage. (Stacy)

I think get the gist strategy are most helpful because it teach me how to identify he important ideas in the passage. (Yuen Sin)

Get the Gist strategy taught me to identify the main purpose of the message which most of the time will be asked in the exam question. (Cai Ying)

\section{Advantages of CSR}

All the students in experimental group thought that they had benefited from CSR. The students had stated a number of advantages of CSR in the interview form to justify the CSR advantages. The most frequently reported advantage of CSR was improving speaking and communication skills. The students stressed that group discussion in CSR help in improving their speaking and communication skills, as noted in the following excerpts:

Besides, it also improve my communication skill as I need to discuss with my friends in a small group. (Stacy)

CSR helps me to improve my English and communication skills because in CSR we need to discuss the point with group mates. (Yuen Sin)

I also need to speak English during the discussion so this increase my speaking skill. (Tiffany) 
The second advantage of CSR mentioned was promoting positive learning attitudes thus increase the autonomy of learners. The interview data suggested that students' autonomy was increased as they needed to be responsible for the assigned role in the discussion. The following statements showed how CSR promoting positive learning attitudes and increasing learners' autonomy:

...in CSR class I can feel my responsibility as I am given a role to perform in the class. (Stacy)

The second advantage is it makes us more independent in learning. In normal class, teacher will read all the thing for us and also do all the explanation but in CSR we need to think all these by our own. (Cai Ying)

...because in CSR we need to discuss the point with group mates. Furthermore, CSR makes me more focused in class. (Yuen Sin)

Because I will be giving a student role in every discussion and it makes me stay focus in the discussion all the time. (Tiffany)

In previous time especially in exam when I see an unknown word I will just give up in finding out the meaning but now I can use the 4 fix up strategies I learnt to help me find the meaning. (Cai Ying)

Besides, the interview data showed that CSR provided a non-threatening learning environment where the students felt more comfortable to talk, to ask questions and to receive assistance. The example was shown as below:

I am afraid to ask teacher questions in the normal class but in CSR group discussion, I can discuss with my group mates if I have any questions or things that I do not understand. (Kai Qi)

Disdvantages of CSR

Apart from the advantages, the interview data also raised some disadvantages of CSR. In the interview, negative aspects of CSR were pointed out by some students. For example,

For disadvantage, sometime all of us do not know how to pronounce a word and we needto wait for the teacher to tell us how to pronounce the word correctly. (Yuen Sin) The disadvantage of CSR is sometime we might stuck at the unknown word or the sentences which are complicated which nobody in the group can explain it. (Cai Ying) In my opinion, the disadvantage of CSR is the discussion time for every passage is different. Sometimes we can finish discuss earlier but sometimes we need a lot of time to discuss. (Stacy)

The two students who are Yuen Sin and Cai Ying proved that unknown words were the most notable impediments to the comprehension of text in CSR.

\section{Dilemmas Encountered in CSR}

In the interview, the students were asked to specify the dilemmas they had been encountered in CSR. 2 of the students stated that they did not face any difficulties in CSR implementation and the other three of them did mention the difficulties faced by them in the interview form. The difficulties faced by them were shown as below:

I need to refer cue cards because I still not familiar with CSR. (Stacy)

At first I am afraid to speak so I do not participate actively in group discussion. (Yuen Sin) 
DEVELOPMENT

Vol. 10, No. 3, 2021, E-ISSN: 2226-6348 @ 2021 HRMARS

Some group mates are shy to speak at first and the teacher need to keep on encourage usto be active in discussion. (Cai Ying)

The statements had shown that the inactive participation due to shyness and unfamiliar with the CSR approach were the dilemmas encountered by the students in CSR.

\section{Willingness to Continue with CSR Approach}

Based on the interview data, all the students agreed and recommended to use CSR in class in learning reading as it was very interesting and helpful in their learning. The examples of students' comments were as follow:

Yes because me myself fell CSR is very helpful in my learning. I can actually use CSR in English class but also in other language classes. (Cai Ying)

Yes because I think it is useful to me in improving my reading. (Tiffany)

Yes because I think CSR do improve my reading skills. (Kai Qi)

I will recommend CSR in class in learning reading because it is fun. (Yuen Sin)

Yes because in normal reading class I will feel very boring but in CSR class I can feel my responsibility as I am given a role to perform in the class. (Stacy)

\section{Discussions}

The data collected from the experimental study is used to answer the first research question. Meanwhile, the data collected from the interview is used to answer the second research question.

4.4.1 Research Question 1 -To what extend will Collaborative Strategic Reading (CSR) affect ESL secondary school students' reading comprehension through online teaching?

As for the first research question, the results did not confirm the positive effect of CSR on the reading comprehension of ESL secondary school students. The analysis of descriptive statistic which is mean suggested that both control group and experimental group made significant improvement after the 10 teaching lessons. When looking at the mean, the experimental group improved significantly over their pre-test. The mean score of experimental group was 24 marks higher from pre-test to post-test while the mean score of control group was 16 marks higher from pre-test to post-test. But when comparing the effect of both CSR approach and traditional teacher-centred approach, there was no significant difference. Hence, the statistical results tend to indicate that CSR approach might not be a better reading strategic approach than the traditional teacher-centred approach in improving the ESL secondary school students' reading comprehension.

This result is not contradictory to expectation as some previous researches have already shown that it was not easy to prove the improved pre-to-post-test comprehension performance in standardized reading measures (Fan, 2009). According to Duffy \& Roehler (1989), readers especially those who are less competent reader need time to restructure their learning experiences successively. Besides, the learners also need a rich context to create a cohesive conceptual framework on how strategies are useful. As the experimental group performed better than the control group in the post-test after the treatment, the potential effect of CSR approach on reading comprehension of students over a longer period of time cannot be ignored.

4.4.2 Research Question 2- What are the ESL secondary school students' perceptions of the Collaborative Strategic Reading (CSR) approach in online teaching? 
The findings from the interview gave insights into the effect and applicability of CSR method in the ESL context. Students' statements supported the effectiveness of CSR approach in improving interest and motivation to learn, improving vocabulary and understanding, improving speaking and communication skills, promoting positive learning attitude, increasing learner autonomy, and providing a non-threatening learning environment. Besides, the disadvantages and dilemmas encountered in CSR also been recognized. The difficulties and obstacles of CSR approach were unknown words, inactive participation due to shyness and unfamiliar with CSR approach.

As for the 4 reading strategies in CSR approach, majority of the participants in this study mentioned in the interview that 'click and clunk' strategy and 'get the gist' strategy are the most useful strategy in improving their reading. In the interview, more than half the number of students stated that click and clunk strategy help them in improving their vocabulary, reducing dependency on the dictionary and thus improving their understanding of the reading materials. While 3 out of 5 students agreed that get the gist strategy helps them in identifying the important points and the main idea in the passage thus had a better understanding of what the passage was about.

The findings of interview revealed that some students faced difficulties in CSR implementation of CSR due to not familiar with it. This indicated that short-time teaching of these 4 reading strategies in CSR may not sufficient for students to apply in specific contexts.

About CSR implementation in ESL secondary school setting, the results revealed that the students agreed and recommended to use CSR in reading class. Nevertheless, more researches are required if it is to implement at other educational settings in Malaysia.

\section{References}

Alamin, A., \& Ahmed, S. (2014). Reading comprehension strategy (CSR) and learners' comprehension: A case study of FLD students. English Language Center. Taif University, KSA.

Alqarni, F. (2015). Collaborative strategic reading to enhance learners' reading comprehension in English as a foreign language. Academic Journal of Interdisciplinary Studies, 4(1), 161-161.

Duffy, G. G., \& Roehler, L. R. (1989). Why strategy instruction is so difficult and what we need to do about it. In Cognitive strategy research (pp. 133-154). Springer, New York, NY.

Fan, Y. (2010). The Effect of Comprehension Strategy Instruction on EFL Learners' Reading Comprehension. Asian Social Science, 6(8).

Fan, Y. C. (2009). Implementing collaborative strategic reading (CSR) in an EFL context in Taiwan (Doctoral dissertation, University of Leicester).

Gani, S. A., Yusuf, Y. Q., \& Susiani, R. (2016). Progressive outcomes of collaborative strategic reading to EFL learners. Kasetsart Journal of Social Sciences, 37(3), 144-149.

Husni, N. A., Manurung, K., \& Kamarudin, A. (2017). The Influence of Collaborative Starategic Reading (CSR) Technique on Students' Acheivement in Reading Comprehension of Narrative Text of the Third Grade Students of Man 2 Model Palu. BAHASANTODEA, 5(4), 41-48.

Javed, M., Eng, L. S., Mohamed, A. R., \& Ismail, S. A. M. M. (2016). Identifying Reading Strategies to Teach Literal, Reorganisation and Inferential Comprehension Questions to ESL Students. Journal of Asia TEFL, 13(3), 204. 
Kabir, F. M., \& Kiasi, G. A. (2018). The Effect of Collaborative Strategic Reading on EFL Learners' Reading Comprehension and Vocabulary Knowledge. European Journal of Foreign Language Teaching.

Karabuga, F., \& Kaya, E. S. (2013). Collaborative strategic reading practice with adult EFL learners: A collaborative and reflective approach to reading. Procedia-Social and Behavioral Sciences, 106, 621-630.

Karimabadi, M., Khonamri, F., \& Mahdavi, O. (2015). Investigating Iranian students' attitude toward using collaborative strategic reading in their reading course. WALIA journal, 31(3), 260-265.

Keengwe, J., \& Kidd, T. T. (2010). Towards best practices in online learning and teaching in higher education. MERLOT Journal of Online Learning and Teaching, 6(2), 533-541.

Klingner, J. K., \& Vaughn, S. (1996). Reciprocal teaching of reading comprehension strategies for students with learning disabilities who use English as a second language. The Elementary School Journal, 96(3), 275-293

Klingner, J. K., Vaughn, S., Boardman, A., \& Swanson, E. (2012). Now we get it: boosting comprehension with collaborative strategic reading. John Wiley \& Sons.

OECD. (2019). Programme for International Student Assessment (PISA) Results from PISA 2018. Retrieved from https://www.oecd.org/pisa/publications/PISA2018_CN_MYS.pdf

Oladele, A. O., \& Oladele, I. T. (2016). Effectiveness of collaborative strategic reading and whole language approach on reading comprehension performance of children with learning disabilities in Oyo State Nigeria Adetoun. International Journal on Language, Literature and Culture in Education, 3(1), 1-24.

Putra, A. K. (2017). The Use of Collaborative Strategic Reading(CSR) to Teach Students' Reading Comprehension of Narrative Ttext (An Experimental Research of the Second Grade Students of SMP Negeri 10 Salatiga in the Academic Year of 2017/2018) (Doctoral dissertation, IAIN SALATIGA).

Rahman, I. F. (2015). The Implementation of Collaborative Strategy Reading (CSR) and its Effects on Students' Reading Comprehension. Eternal (english, teaching, learning, and Research Journal), 1(1), 39-56.

Richard, N. (2019). What Is English as a Second Language?. Retrieved from https://www.thoughtco.com/english-as-a-second-language-esl-1690599

Rizka, A. (2011). THE EFFECT OF COLLABORATIVE STRATEGIC READING TOWARD STUDENTS'ENGLISH READING COMPREHENSION AT THE SECOND YEAR OF SMPN 1 SINGINGI HILIR (Doctoral dissertation, Universitas Islam Negeri Sultan Syarif Kasim Riau).

Rosa, C. H., \& Yahmun, Y. (2019). Implementing Collaborative Strategy to Improve Reading Comprehension the Eleventh Graders of Smk Kertha Wisata Malang. Journey: Journal of English Language and Pedagogy, 2(1), 60-66.

Rozak, R. R. (2013). The Effectiveness of Collaborative Strategic Reading (CSR) to teach content area reading comprehension viewed from students' intelligence. Surakarta: Sebelas Maret University.

Standish, L. G. (2005). The effects of collaborative strategic reading and direct instruction in persuasion on sixth-grade students' persuasive writing and attitudes (Doctoral dissertation). 
Vaughn, S., Klingner, J. K., \& Bryant, D. P. (2001). Collaborative strategic reading as a means to enhance peer-mediated instruction for reading comprehension and content-area learning. Remedial and Special Education, 22(2), 66-74.

Wang, T. H. (2008). The effects of modified Collaborative Strategic Reading on EFL learners' reading comprehension. Unpublished MA dissertation, National Changhua University of Education, Changhua, Taiwan.

Zoghi, M., Mustapha, R., \& Maasum, T. N. R. B. T. M. (2010). Collaborative strategic reading with university EFL learners. Journal of College Reading and Learning, 41(1), 67-94. 